\title{
LEGAL EDUCATION IN INDIA: PROBLEMS AND CHALLENGES*
}

\author{
B. C. Nirmal ${ }^{* *}$
}

\begin{abstract}
This article makes some observations about legal education in India by locating it within a wider context of legal education reform that is taking place in Law Schools across the world in the wake of globalizationled and globalization-induced changes in the nature and needs of legal profession. For being both intellectually challenging and professionally relevant, legal education should be more responsible than ever before to the legal needs of the community national as well as international, and the learning needs of
\end{abstract}

This is a revised version of Key Note address delivered by the author on the eve of dedication of Siksha 'O' Anusandhan, National Institute of Law on $17^{\text {th }}$ September, 2011, SOA University, Bhubaneshwar, Orissa, India. The author is thankful to Professor R. Patnaik, Director of the National Institute of Law and Professor Jaideo Pati, Former Dean, Faculty of Law, Utkal University for their valuable comments on an earlier draft of this paper.

Dean and Head, Law School, Banaras Hindu University; Professor of Law, Faculty of Law, Banaras Hindu University, Varanasi - 221 005; Member, Executive Council, Indian Society of International Law, Member, Editorial Board, Indian Journal of International Law and VicePresident of All India Law Teachers Congress, New Delhi. E-mail: bcnirmalbhu@gmail.com. 
students to become professionally competent to play their role in an increasingly transnationalized legal service market. Any effort to restructure and reorient legal education to attain these goals will be an uphill task for any school. This article begins with exploring the implications of globalization for legal education and then turns to nature, aims and objectives of legal education. The article then looks at the possible changes required to be made in the existing curriculum for undergraduate law students in order to make the legal education more relevant and meaningful for its consumers. The focus then shifts to issues concerning methods of teaching, clinical experience and assessment of students. This article then considers issues arising from the proposal of the Bar Council of India to reduce the period of Masters programme and then builds a strong case for strengthening a research tradition in Law Schools. The focus then shifts to measures that are necessary to attract and retain better faculty and also to the regulatory role of the Bar Council of India in the field of legal education. The article concludes with some reflections on the promise of a different vision of legal education.

Keywords: legal education, India, globalization, reform, curriculum changes, Bar Council of India.

\title{
PENGAJIAN UNDANG-UNDANG DI INDIA: MASALAH DAN CABARAN
}

\begin{abstract}
ABSTRAK
Makalah ini membuat pemerhatian tentang pengajian undang-undang di India dengan meletakkannya dalam konteks pembaharuan pengajian undangundang yang lebih luas yang berlaku di Sekolah
\end{abstract}


Undang-undang di seluruh dunia berikutan perubahan yang dipimpin dan didorong oleh globalisasi kepada sifat dan keperluan profesion undang-undang. Kerana ia mencabar daya fikir dan berkaitan dengan profesion, pengajian undangundang hendaklah lebih bertanggungjawab daripada sebelumnya kepada keperluan undangundang masyarakat nasional dan antarabangsa, dan kepada keperluan pembelajaran pelajar untuk menjadi cekap mengikut profesion agar dapat memainkan peranan mereka dalam pasaran perkhidmatan undang-undang transnasional. Sebarang usaha untuk mengatur dan menyesuaikan semula pengajian undang-undang untuk mencapai matlamat-matlamat ini akan menjadi tugas yang sukar bagi mana-mana sekolah. Makalah ini bermula dengan menjelajah implikasi globalisasi ke atas pengajian undang-undang dan kemudian beralih kepada sifat, hasrat dan tujuan pengajian undang-undang. Makalah ini kemudian melihat kepada perubahan-perubahan yang mungkin perlu dilakukan dalam kurikulum sedia ada untuk mahasiswa undang-undang supaya menjadikan pengajian undang-undang lebih berkaitan dan bermakna untuk pengguna. Fokus kemudian beralih kepada isu-isu berkaitan kaedah mengajar, pengalaman klinikal dan penilaian pelajar. Makalah ini kemudian mempertimbangkan isu-isu yang timbul dari cadangan Majlis Peguam India untuk mengurangkan tempoh program Sarjana dan kemudian membina sebab yang kukuh untuk memperkuatkan tradisi penyelidikan di Sekolahsekolah Undang-undang. Fokus kemudian beralih kepada langkah-langkah yang perlu untuk menarik dan mengekalkan kakitangan akademik dan juga kepada peranan pengaturan Majlis Peguam India dalam bidang pengajian undang-undang. Makalah ini disimpulkan dengan sebahagian bayangan janji satu visi pengajian undang-undang yang berbeza. 
Kata kunci: India, pengajian undang-undang, globalisasi, perubahan, perubahan kurikulum, Majlis Peguam India.

\section{INTRODUCTION}

Legal education reform is taking place around the globe to make it more responsive than ever before to the legal need of the community-national as well as global and the learning needs of students to become professionally competent to play their role in our increasingly interdependent world. The focus of legal education reform in other parts of the world is on integration of cross-border and international dimensions of practice with the existing curriculum, with greater emphasis on problem-solving, negotiation and transnational practice in the curriculum and balancing it with the traditional curricular focus on litigation, use of new technology and a greater use of clinical legal education for bridging the existing gaps between theory and practice of law.

In India, legal education has been on the agenda of the government for more than six decades. Government bodies, including the Law Commission of India, University Grants Commission, and the Bar Council of India have taken several initiatives towards improvement of legal education. The National Knowledge Commission and a 3-member Committee created by the apex judiciary have also recommended legal education reforms, some of which have been implemented and some of which are pending. Legal educators have also contributed in their own modest ways to the current debate on legal education reform.

\section{NEED FOR LEGAL EDUCATION REFORM}

\section{(i) Globalization and Legal Profession}

Although the ongoing processes of economic globalization have received a serious blow in the wake of the recent global financial meltdown, changes brought about by globalization in law $^{1}$ and in the legal profession

For the meaning of globalization and its implications for the modern conception of law and legal system, see B.C.Nirmal. 'Sovereignty in International Law.’ Soochow Law Journal. 3 (2006), 1-51, at 41-48. 
require law schools to bring global perspectives to legal education and impart such skills to students as are necessary for them to join the legal profession in the increased transnationalized legal service market. As we all know, the traditional legal profession and legal education are essentially based on the conceptions of legal modernity and modern legal thought. But the advent of globalization undermined some deep-rooted assumptions of modern legal thought by laying emphasis on the pluralization and diversity of legal orders and the need to recognize other forms of legal ordering in addition to municipal law and public international law. ${ }^{2}$ The assault of globalization on the culture specificity of law and the resultant need to construct a theory of law that reaches across legal cultures, ${ }^{3}$ on the one hand and the increasing juridification of human relations, transactions and events, ${ }^{4}$ on the other along with other globalization-induced changes in law present both new opportunities and challenges before our law schools to reorient and restructure legal education according to the changing needs of legal profession in a globalized interdependent world.

Globalization by nature is hegemonistic and so are 'globalized localism' and 'localized globalism.' But globalization may also be counterhegemonistic and subaltern cosmopolitism and the common heritage of humankind belong to this category of globalization. Needless to say, for being both intellectually challenging and professionally relevant, legal education needs to reflect the reality of globalization and its implications for legal practice.

In response to the challenges arising from globalization many law schools in the United States are making conscious and sincere efforts to incorporate transnationalization into legal education by incorporating transnational law, world law and global law courses in the law curriculum.

\footnotetext{
$2 \quad$ S. Veiteh, E. Christodoulis and L. Farmer, Jurisprudence: Themes and Concepts, (2007, Routledge-Cavendish), 200-202.

Ibid.

See generally: J.Habermas, The Theory of Communicative Action, Vol. 2; Life, World and System. (1987, Cambridge: Polity Press); Santos, Towards a New Legal Common Sense (2 ${ }^{\text {nd }}$ edition, London: Butterworths), 55-61; R. Cotter Nell, The Sociology of Law: An Introduction (1992, London: Butterworths), at 65-70 and ch.9; R.M. Unger, Law in Modern Society (1976, New York: The Free Press), 58$66,192-223$.
} 
In view of the international dimensions of legal practice today, we need lawyers who can look beyond the law of the jurisdiction in which they practice and forge new tools and techniques appropriate to the changing needs and times. In this context, what Broadly says is of much relevance: "... in order to be an accomplished lawyer, it is necessary, besides having knowledge of the law, to an accomplished man graced with at least a general knowledge of history, of science, of philosophy, of useful arts of the modes of business and of everything that concerns the well being and intercourse of men in society. He ought to be a man of a large understanding; he must be a man of large acquirements and rich in general information; for he is a priest of the law, which is the bond and support of civil society and which extends to and regulates every relation of one man to another in the society, and every transaction that takes place in it. Trained in such profession and having these acquirements, and two things more, incorruptible integrity and a high sense of honour...." Although to produce a lawyer of these qualities is certainly a tall order for our law schools, all possible efforts need to be made to achieve this goal of legal education.

The need for a lawyer who is well-equipped to provide legal services beyond national frontiers has given the impetus necessary for the global law school movement. A global law school may be described as "a centre of thought, where a broader range of opinion is found than in local law schools, with a multinational faculty and student body, and a programme to produce lawyers capable of success worldwide." ${ }^{\text {P Pursuant }}$ to the goals of internationalization, many law schools in the United States have undertaken activities necessary for internationalization of their campuses.

\section{(ii) WTO Agreement and Legal Education}

Sooner or later foreign universities and foreign legal firms / individual lawyers will enter educational service sectors and the legal service market.

Alexander H.E., Morawa \& Xialolu Zhang, 'Transnationalizing of Legal Education: A Swiss and Comparative Perspective, Penn State International Law Review (2008), 811, 817; see also David S. Clark, 'Transnational Legal Practice: The Need for Global Law School's, Am J. Comp. Law, 46 (1998), 261. 
As a party to the General Agreement on Trade in Services (GATS) India is duty bound to accord 'most favoured nation' status, market access and national treatment to other member countries of the World Trade Organization. As a consequence, it is not possible for the Government of India to prevent indefinitely the entry of foreign lawyers and foreign universities into India. Any misadventure on the part of the Government of India in this regard will amount to an infringement of the provisions of GATS. Both wisdom and prudence therefore demand that before foreign universities and foreign lawyers enter the domestic market, India should re-structure and re-orient its legal education and legal profession to meet the new challenges in the context of globalization. In the changed scenario, legal profession requires lawyers to represent clients not only within but also outside national frontiers. Accordingly, to enable our law graduates to practice law both domestically and internationally in a highly competitive legal service market, law schools should include within their curriculum subjects like information technology, corporate law, taxation, human rights, bankruptcy laws, commercial law, women rights, alternative dispute resolution, cyberlaw etc. Students should also be encouraged to learn at least one foreign language, increase cultural familiarity with the legal systems of other countries, develop communication skills and sharpen professional skills for the purposes of transnational legal practice. Students also need to be educated about concepts like group, dispute, institution, process, function, decision, regulation, efficiency, effectiveness etc. as part of general jurisprudence course for enhancing their understanding of cross-legal cultures.

\section{(iii) Influence of US Legal Education}

The US model of legal education continues to influence legal education in other parts of the world. Japan and Korea have moved to adopt J. D. style graduate law degrees. In Australia, the University of Melbourne has adopted a similar approach. Efforts are underway in Hong Kong and the Phillippines to adopt the US model of legal education, where the J. D. is offered alongside the LL.B. If this trend continues, England will probably remain outlier with its three-year graduate programme. The globalization of legal education movement has led to the establishment of double degree programmes across national jurisdictions. The NYU School of Law and National University of Singapore Dual Degree Programme 
is an example of such programmes. It offers Master of Law degree from each of the partner institutions, but is taught entirely in Singapore with NYU faculty flying in during the northern summer months. US Law Schools have moved from the old exchange programme to doubledegree programmes. Cornell University Law School, for example, offers double degrees in partnership with universities in France and Germany. Columbia Law School also has partners in France and Germany as well as England. NYU has partnership with Osgoode Hall Law School in Canada and the National University of Singapore. And American University Washington College of Law has partnership with Universities in Canada, Spain, France, England, the Netherlands, Hong Kong, Korea, South Africa, and Uganda.

In India, national law universities are influenced by the US model of legal education. Sooner or later double degree programmes will also be replicated in a big way here. The question that deserves serious consideration in this context is whether the goal of a global law school can be achieved by simply incorporating US ideas or there is also a need to make it global by having a genuine engagement with the people and the places that constitute today's global profession.

\section{NATURE OF LEGAL EDUCATION}

Without entering into the perennial debate on whether legal education is liberal or professional, it is submitted that it is a de facto combination of both, a view already held by legal educators in countries like Australia. We agree that legal education has a liberalizing effect but sadly our law schools have failed in training students for the legal profession and producing liberalizing effect in law graduates. At any rate in the present materialistic world the best brains can be attracted to law schools only when the education imparted to them is capable to secure economic stability and prosperity for our law graduates. For obvious reasons, legal education should be such which prepares our students to meet the economic challenges of life that awaits them around the corner. It follows that a student should be prepared not only for playing a role in the traditional profession but also in diverse other fields where the knowledge of law and training in the techniques of legal profession are required. On this understanding, legal education is a career-oriented education. Adhering to this point of view, we do not mean that legal education should 
be commercialized. Rather, it is humbly submitted that law schools are not commercial colleges and hence they should not go for commercialization of legal education at all.

\section{AIMS AND OBJECTIVES OF LEGAL EDUCATION}

Legal education in a country, whether developed or developing, operates in a particular socio-economic and political context and aims to fulfill the needs of society by producing law graduates who are competent enough to take up a wide range of responsibilities as legal professionals. In the beginning legal education aimed at producing lawyers for the courts, and its content was then dictated by the demands of legal profession. But today legal education has to meet not only the requirements of the Bar but also of the new needs of trade, commerce and industry in the context of growing internationalization of the legal profession.

Modern legal education in India was started by the British and its principal concern was to acquaint Indians with rules of law which would help the British in the administration of the country. Legal education in the pre-colonial period imparted only certain information to the students without developing critical perspectives and analytical insights among law students and was marked by the rote system. Even after the independence of the country the same age-old syllabus of courses continued without readjusting the same according to the changed needs of an independent-nation state and the goals the Indian Republic had set out for itself in the preamble to the Constitution. No wonder, the state of legal education remained unsatisfactory for many years until a fresh breeze of new thinking entered the realm of legal education and initiatives aiming at the reforms in legal education were taken at several levels.

While the Radhakrishnan Committee (University Education Commission 1948-49), the Bombay Legal Education Committee (1949) and the Setalvad Committee (1954) showed their disillusionment and dissatisfaction with legal education in their respective reports and drew attention to its defects and deficiencies, it was the Gajendragadkar Committee (1970) which could be credited for articulating the objectives and aims of legal education in India by taking into account the perceived needs of such education in a country dedicated to the rule of law, democracy, constitutionalism, social, economic and political justice and respect for fundamental rights and basic freedoms. The 'aim of legal 
education,' said the Gajendragadkar Committee, 'would be to make the students of law good lawyers who have absorbed and mastered the theory of law, its philosophy, its functions and its role in a democratic society.' Numerous changes have taken place in both legal education and legal profession since then which in turn require a re-articulation of the aims and objectives of legal education. The National Knowledge Commission, while deliberating on the issues related to knowledge has made a modest attempt in this regard when it, after recognizing legal education as 'an important constituent of professional education' stated thus: ${ }^{6}$

"The vision of legal education is to provide justiceoriented education essential to the realization of values enshrined in the Constitution of India. In keeping with this vision, legal education must aim at preparing legal professional who will play decisive roles, not only as advocates practicing in courts, but also as academics, legislators, judges, policy makers, public officials, civil society activists as well as legal counsel in the private sector, maintaining the highest standards of professional ethics and a spirit of public service. Legal education should also prepare professionals equipped to meet the new challenges and dimensions of internationalization, where the nature and organization of law and legal practice are undergoing a paradigm shift. Further, there is need for original and path-breaking legal research to create new legal knowledge and ideas that will meet these challenges in a manner responsive to the needs of the country and the ideas and goals of our Constitution.”

As is evident from the above, the aim of legal education is to provide justice-oriented education and produce competent legal professional to fulfil diverse legal needs at home and abroad and undertake original and path breaking legal research to create new legal knowledge and ideas to meet new challenges facing the society. Simply put, the aim of legal education according to the NKC Report is to produce professionals

$6 \quad$ National Knowledge Commission, Compilation of Recommendations on Education (Oct, 15, 2007): http:// www.knowledgecommission.gov.in/ recommendations/legaleducation.asp. 
who are equipped for law practice in the global legal environment and who can serve the interests of Indian citizens, business, government and NGOs and provide transnational legal services in a highly competitive interdependent and interconnected globalized world.

The Vision Statement 2010-2017 of the Chairman of the Bar Council of India of June 2, 2010 made a promise to the Nation, of 'ensuring equality before the law and the supermacy of the rule of law in the Indian democracy.' The Vision Statement identified inadequate quality of legal education and infrastructure and lack of relevant skills training to meet the ever-changing demands of the modern world, as two of the issues affecting the image of the legal profession in India and identified as one of the steps towards resolving these issues as 'creating clear quality standards for legal education and a common entry standard for entering law schools across the country.' What is most interesting in the Vision Statement is its understanding that Indian legal education should be 'value creating' not only for "top of the pyramid" law graduates but must also have 'stringent minimum standards' so that 'it is transformational for all students,' irrespective of the law school that they choose to graduate from.

\section{CURRICULUM DEVELOPMENT}

Curriculum is a necessary tool for the realization of the vision, aims and objectives of legal education. But curriculum development is a continuous process and as such should be carried on from time to time by the regulatory authorities in consultation with law schools and law teachers for making legal education more relevant and meaningful for its consumers. In India, national law universities and law colleges offer a three year Bachelor Law Degree (B.L/LL.B.) and a five year integrated undergraduate degree (B.A. LL.B., B.Com. LL.B., B.Sc. LL.B. and B.B.A. LL.B.). ${ }^{7}$ The current policy of the Bar Council of India (BCI), which is the supreme regulatory body to regulate the legal profession in India and prescribe the curriculum and syllabi for undergraduate course, ${ }^{8}$

\footnotetext{
$7 \quad$ BCI, Rules on Standards of Legal Education and Recognition of Degrees in Law for purpose of Enrolment as Advocate and Inspection of Universities for Recognizing its Degree in Law, (2008).

$8 \quad$ Section 7 (i) (h), The Indian Advocates Act, 1961.
} 
has been to encourage only five year, dual degree LL.B. Programmes. A recent legal education reform document of BCI states that 'moving forward, only five year dual degree LL.B. programme would be recognized by the Bar Council of India (BCI)' but at the same it also adds that 'BCI will continue to encourage three year LL.B. course for specialized areas such as Intellectual Property Rights, which are undertaken by postgraduates.'

As the matter stands now, the curriculum prescribed by BCI for each of the degree programmes LL.B. and B.A. LL.B. is mandatory for all law colleges and university departments of law. The BCI curriculum mandates students to take not less than twenty-eight law subjects, eighteen compulsory substantive law subjects and four compulsory clinical papers. They are required to take six optional papers from three or more groups of elective topics, and for a specialized and / or honours course to take an additional eight papers from one group. The list of elective groups that may be offered is robust, including Constitutional Law, Business Law, Law and Agriculture and Intellectual Property Law. In addition to this, BCI allows a university / school to add other subjects and groups to its curriculum.

But even with this robust and ambitious LL.B. curriculum the quality of legal education in India is perceived by stakeholders to be poor in comparison to its counter-parts in the United States, Western countries and Australia and New Zealand. Precisely for this reason, the Knowledge Commission of India, in its Report to the Prime Minister, laid too much stress on the curriculum upgradation and recommended the constitution of a committee consisting of among others faculty and practitioners to discuss curricula, syllabi and reading material of all core and optional courses, and devise 'model' syllabus for all core and optional courses. For its part the Commission while suggesting the ground rules for the development of a model syllabus for the LL.B. courses stated thus: "Law teaching must be interwoven with related contemporary issues, including international and comparative law perspectives. The curricula and syllabi must be based in a multidisciplinary body of social science and scientific knowledge. Curriculum development should include expanding the domain of optional courses, mainstreaming legal aid programs and developing innovative pedagogic methods, legal education must also be socially engaged to sensitize students to issues of social justice."

We agree but humbly submit that curriculum development is not mere an addition - subtraction exercise but instead a serious exercise 
contingent upon which is the very realization of the aims and objectives of legal education. For being meaningful and realizable a curriculum should not only clearly reflect the objectives of legal education and demands of legal profession - national as well as international, but also should be in consonance with the learning needs of students, availability of competent faculty expertise and infrastructure, and social realities. Needless to say, any attempt to foist a curriculum on law colleges and law teachers by BCI in the name of ensuring of uniform standards of legal education throughout the length and breadth of such a large and varied country as India without consulting law teachers and their professional organizations is bound to fail. Although BCI now realizes the need to recognize faculty autonomy in the design and implementation of the revised curriculum, which it is expected to put in place shortly, its earlier policy to impose its curriculum on law schools / colleges did more harm than good to legal education in our country. As aptly observed by a well known legal educationist, 'the highly mandated curriculum places Indian law schools at a competitive disadvantage in responding to the fast changing profession of law and global trends in legal education.'

Compare the approach of BCI with that of the UGC which presented a model syllabi in a spirit of openness and continuous improvement and as a 'broad common framework for exchange, mobility, and free dialogue across the entire India academic community.' It is therefore humbly submitted that Law schools and universities must be allowed enough autonomy and freedom of action to frame courses according to specific needs.

Considering that every curriculum whether prepared by BCI or any university / college always leaves scope for improvement, there is still need for a spirited debate on curriculum development by informing the same with recent reform trends in other parts of the world. The first reform trend relates to the need for a paradigm shift from litigationfocused traditional curriculum to one with greater emphasis on problem solving, negotiation, and transactional practice. The need for such paradigm shift emanates from the nature of transnational legal practice itself. The globalization-induced increasing demand for crosss-border

$9 \quad$ See Jane E. Schukoske, 'Legal Education Report in India: Dialogue Among Indian Law Teachers,' Jindal Global Law Review, 1 (2009), 251-279, at 265. 
legal services requires that lawyers are not only aware of several national, international and supranational legal systems and cultures but are also equipped with problem solving, negotiation and transactional practices because much of transnational legal matters are amenable to solutions not through litigation but rather are to be managed through advance planning and agreement. The new professional role demanded from international lawyers requires them to work with managers in commerce and management and manage international legal matters. To be able to solve such matters a lawyer should be 'both intellectually and culturally flexible and capable of adapting not merely to new laws but to new jurisdiction.' ${ }^{10}$

It must be recognized that law has moved from internationalization to transnationalization and now to globalization. Legal practice should therefore also move forward from something with an exclusive focus on litigation to problem-solving and management of international legal matters. To operate effectively in a globalized legal market individual lawyers need to be comfortable in multiple jurisdictions, often simultaneously. Law schools should therefore produce law graduates who can serve their foreign clients as "residents" rather than "tourists" in new jurisdictions. World has moved from archipelagoes of jurisdictions to patchwork of archipelagoes of jurisdictions and now to web of jurisdictions. Law schools should also respond to this change by reflecting this in their LL.B. curriculum.

As noted by the American Bar Association in its 1992 Report (known as the MacCrate Report) ${ }^{11}$ much of the work of a lawyer involves analysis of the facts of a client's case, research of the applicable law, counseling, structuring of transactions and negotiations for settlement of disputes before or outside of court. In consequence, to make a new lawyer well equipped to serve his client he should be taught the following lawyering skills during the study at the university / college: problemsolving, legal analysis and reasoning, legal research, factual investigation, communication, counseling, negotiation, litigation and alternate dispute resolution procedures, organization and management of legal work, and identification and resolution of ethical dilemmas. Besides imparting these skills, law schools should impart certain values to law students as well.

\footnotetext{
10 See Simon Chesterman, 'The Globalisation of Legal Education,' Sing J. Legal Stud (2008), 58.

11 Schukoske, n. 9, at 258-59.
} 
The values to be taught to students, according to the MacCrate Report are competence, commitment to justice, improvement of the profession, and continuous learning and pursuit of employment consonant with personal and professional goals.

A 2007 high profile report (the Carnegie Report) ${ }^{12}$ has called for legal education strategies in which the cognitive, the practical and the ethical-social dimensions of lawyering would be holistically integrated in law school's education curriculum. The Report calls for integration of theory, skill development and ethical judgment in law school education. The last element of the curriculum requires a theoretical as well as practical emphasis on inculcation of the identity, values and dispositions consonant with the fundamental purposes of the legal education.

In the United States a group of clinical educators have advocated the adoption of the 'outcomes model' by law school. ${ }^{13}$ This model calls for identification of the desired outcomes from legal education in terms of knowledge, skills, and professional attribute. It also requires framing of a curriculum in consonance of the identified outcomes, making students aware of these outcomes and what is expected from them in the duration of their study. This model of legal education not only calls for shift from an excessive emphasis on the teaching of substantive laws to the development of skills and professional attributes but also for a systematic change in the evaluation methods in which focus is not in memorizing of the legal principles but in measuring student's proficiency in the context of the outcomes articulated.

Since the Bar Council of India has also expressed its desire to encourage the adoption of this model in order to embellish language, computer, and public speaking skills, law schools should develop the learning outcomes in consultation with the bar and bench and consistent with the law school's mission. In developing the learning outcomes they may take the help of 'Best Practices for Legal Education' prepared by the US legal educators. Some of the core general characteristics and abilities needed by lawyers may be as follows: appropriate behaviour and integrity in a range of situations, including contentious and noncontentious areas of work, communication technique needed for communicating effectively with clients, colleagues and members of the profession, recognition of clients' financial, commercial and personal

\begin{tabular}{ll}
\hline 12 & Ibid. \\
13 & Ibid, at 260.
\end{tabular}


constraints and priorities, skills of problem-solving, ability to recognize and resolve ethical dilemmas and use risk management skills, capacity and desire to work as part of a team, ability to recognize personal and professional strengths and weaknesses to identify the limits of personal knowledge and skills and to develop strategies that will enhance their personal performance, skills and abilities to manage personal workload and manage efficiently and concurrently their personal performance, and the capacity to deal sensitively and effectively with clients, colleagues and others from a range of social, economic and ethnic backgrounds. Law schools should also impart training to equip students with the capacity to identify and respond positively and appropriately to issues of culture and disability that might affect communication techniques and influence a client's objectives.

Our law schools will do well if they impress upon students that legal education is a life-long learning process. The Australian Law Reform Commission stressed on this aspect of legal education when it observed thus: ${ }^{14}$

\begin{abstract}
"Accompanied by a commitment to facilitating "lifelong learning” for professionals, Australian law schools might consider adoption of an underlying philosophy which holds that (i)n a changing environment, the best preparation that a law school can give its students is one which promotes intellectual breadth, agility and curiosity, strong analytical and communication skills; and a (moral / ethical) sense of the role and purposes of lawyers in society.”
\end{abstract}

While framing a curriculum for law students the legal educators should give due importance to training of students in the use of new communication technologies in view of the increasing importance of such technologies in promoting the learner-centered education and making legal education participatory, practical and intellectually stimulating. By allowing for collaboration and discussions amidst faculty and students across the countries these technologies have enormous potentiality to

$14 \quad$ Australian Law Reform Commission, Managing Justice: A Review of the Federal Justice System, Ref. No. 89, 912.89 (1999), available at http://www.austlii.an/other/alrc/publications/reports/89. 
give new meaning to learning and teaching process. The knowledge of communication technologies will help students to have access to uptodate information and a wealth of resources available on websites. And with new tools like open courseware blogs, social networks, audio and podcasting and video conferencing both students and teachers can share information and develop collaborative approach in creating new course content and teaching materials. Online-teaching and informal communications among law students and faculty across the country will encourage debate, and discussion on aspects of law and legal education.

Given the advantages of the use of new technologies in legal education, it is heartening to note that both the Knowledge Commission and the Bar Council of India have suggested a greater use of such technologies in law schools. The Knowledge Commission (2006-09) has recommended that all information available in the India Law Institute, Supreme Court Library, Indian Society of International Law as well as those of all law schools, universities and public institutions in the country, be networked and digitized. Besides, the Bar Council has decided to identify software that may be used to counter plagiarism in publications and students assignments.

In order to fully harness the educational potentialities of the curriculum suggested above, resource materials should be designed in such a manner as could bring inter-disciplinary and multi-disciplinary perspectives to students and sensitize them to social concerns like poverty, unemployment, gender-justice, upliftment of poor and downtrodden sections of society and social justice. Considering that one basic objective of legal education in a country like India is to make students better educated citizens as well as lawyers, emphasis should be given on the attainment of socialization objectives of the legal education by providing them opportunities for various kinds of educational experience. Students should also be exposed to the phenomenon of the trans-nationalization of the events, transactions, consequences etc. as well as the globalization of the economy and their implications for law, legal profession and legal education. To practice law domestically or transnationally, law graduates need to be well-informed of the transnational dimensions of the market place and communication, the existence of multinational and multicultural communities and also of our global challenges.

The LL.B. curriculum should also aim to equip law students with diverse perspectives on the nature, role and functions of law in the society. To make the point clear, liberal legal scholarship portrays the 
law as rational, coherent, necessary and just, but as emphasized by the critical lawyers, law is arbitrary, contingent, unnecessary and profoundly unjust. Liberal legalism, say the critical lawyers, represent the status quo in society and masks the injustice of the system. Mainstream legal theories not only mask the underlying contradictions in the law but also the deep-rooted hierarchies of power that are hidden beneath the neutral exterior of the law. As neither education is politically neutral nor is so the discipline of law, it is necessary that students should also be made well acquainted with Kantian 'law of peoples,' Benthamite general jurisprudence, Derradian 'deconstruction theory' and the Marxian theory of 'law as a super-structure.' ${ }^{15}$

Coming to the medium of instruction, the Bar Council has taken the view that English must be the medium of instruction at all law schools and this would be a mandatory and strict requirement for accreditation of the law schools. This is certainly a controversial view given the fact that language is both a sensitive and emotive issue. Considering that our Constitution guarantees linguistic justice to all and the language of proceedings in subordinate courts, where the majority of consumers of justice go in the first instance, is the regional language, issues relating to medium of instruction should be left to be decided by universities and law colleges. Because it is they who can take appropriate decision in the matter after taking into account the learning needs of students and the legal need of the community within which they operate. The Bar Council's excessive emphasis on the uniformity of standard of legal education through the same or identical aims and objectives set out for such education and uniform admission procedure and above all the same legal curriculum in the past did more harm than good to the quality of legal education in our country. Time has now come to move from the old outdated and impractical approach to legal education to a realistic, pragmatist and scientific approach in this regard and to infuse the elements of autonomy, flexibility, and diversity in the field of legal education.

$\overline{15} \quad$ For recent trends in legal theory challenging the mainstream see; Denise Meyorson, Understanding Jurisprudence (2007, RouteledgeCavendish), at 89-116. 


\section{METHODS OF TEACHING, CLINICAL EXPERIENCE AND ASSESSMENT OF STUDENTS}

The value of syllabus of study lies not merely in its content but also in the manner in which students are exposed to the contents of the course. This in turn warrants appropriate changes in the method of teaching of the courses of study. The traditional Socratic / lecture method played a significant role in imparting knowledge to law students in the past and continues to be a far-reaching importance as a mode of instruction even today at universities and colleges where the number of students is large, faculty expertise limited and infrastructure facilities meager. Despite the canards spread by its critics in the traditional lecture method teachers do not transfer only ready-made knowledge but newly-created knowledge imbued with practical experience, principles derived from the case law, their own perspectives and thoughts on the subject to students and thereby strive to impart what is known as holistic legal education to its consumers. Though historically, it is a teacher-centered teaching method, it is amenable to be made learner-centered, participatory, and profession-oriented method of teaching, if the teachers concerned work in that direction.

The cases and materials method and the Langdellian method are also in use in some Indian law schools. The Banaras Law School adopted this method in the early 1960's but later on abandoned it because of some unavoidable circumstances. In this method, synopsis of lectures and case books are supplied to students in advance and students concentrate on appellate decisions, analyse them and identify principles of law laid down therein. Christopher Langdell, who pioneered this method of study of law, was of the view that '(L)aw is a science and ... all the available materials of that science are contained in printed books ... We have also constantly inculcated the idea that the library is the proper workshop of professors and students alike; that it is to us all that the laboratories of the university are to the chemists and physicists, the museum of natural history to the zoologists, the botanical gardens to the botanists.' But like other methods, this method too has its own limitations and can only prepare academic as opposed to professional lawyers. It should therefore not come as a surprise that Jerome Frank, a noted jurist of the realist school of jurisprudence found it necessary to assail the Langdell system in these words: 


\begin{abstract}
"Students trained under the Langdell system are like future horticulturists confining their studies to cut flowers, like architects who study pictures of buildings and nothing else. They resemble prospective dog breeders who never see anything but stuffed dogs. And it is beginning to be suspected that there is some correlation between that kind ot stuffed dog study and the overproduction of stuffed shirts in the legal profession.”
\end{abstract}

In an obvious rebuff to Langdell method, Oliver Wendell Homes Jr also once said, "the life of the law has not been logic, it has been experience.” So if the legal education has to be both intellectually stimulating and professionally relevant, the case method must be accompanied by practical training and some sort of clinical experience.

In India, practical training and clinical legal education are integral parts of the curriculum in undergraduate programmes of law and occupy an important place on the educational agenda of the national law universities and premier school of law. Four papers in the LL. B. curriculum prescribed by the Bar Council of India relate to practical training (including clinical legal education). Grounded in the pedagogy of learning by doing, 'clinical legal education programme' may be a useful tool to prepare students for learning the law, through experience by performing the variety of roles that lawyers are expected to play in the society. When properly designed and implemented, the clinical legal education programme in law schools will enable students to learn not only the professional skills but also acquire deepening understanding and sound knowledge of the law and the role of legal profession in society.

It is because of the above mentioned pedagogical importance of the clinical legal education that the Bar Council of India, vide Resolution dated October 24, 2009, resolved that all schools / colleges should establish a legal aid clinic / centre for the purpose of providing inexpensive and efficient justice to the needy sections of society. The Council also resolved that a lecturer shall be the faculty in charge of a legal aid clinic / centre, and the final year students would be trained at such legal aid clinics / centres in imparting professional legal advice and client interaction. A three-member Committee established by the Supreme Court not only endorsed the said Resolution passed by the Bar Council but also recommended that establishment of such legal aid clinics / centres be made a precondition to the recognition of law colleges by the Bar Council. 
While law schools across the country recognize the centrality of practical training and clinical legal programme in legal education, many of them are hardly in a position to run these courses in a befitting manner because of the resource crunch and the lack of faculty expertise in providing such education. Indeed, planning practical training objectives, managing clinical teaching and designing the programme, supervision and evaluation continue to be a daunting task for most of the law schools and colleges. As we all know, full time law teachers are unable to impart practical training and clinical experiences to students due to lack of their experience at the bar. The problem is further compounded by the fact that while a practising advocate may teach law as a part time lecturer, full time faculty cannot practice law, though he / she may seek permission to appear in a particular case. The role of university policies in various matters may also have a bearing on the teaching of the practical training and clinical legal education courses. To bring about an improvement in the teaching of these courses a national institute of legal education should be established for the purpose of extensive teacher-training programmes. Law schools with adequate resources at their disposal should engage practising advocates as part time lecturers for running their legal aid clinics and providing training to students. They should also arrange internship of students at law firms, lawyers' chambers and nongovernmental organizations associated with human rights protection, environmental protection and women empowerment and gender justice. In addition, University Grants Commission (UCG) should explore the possibility of granting six months to one year professional leave for law teachers to enable them to gain practical experience in the courts of law. Last but not least, clinical law teachers should be given due credit and recognition for their work at the time of selections and promotions. It should be recognized by all concerned that law schools can attract many good students towards legal education only when the faculty members have a combination of academic knowledge, practical experience, and professional proficiency.

Coming to the mode of examinations and assessment, appropriate methods need to be devised to measure the ability of students in terms of critical analysis and appreciation of law and its operation in society. Examinations should no longer be a test of the memory and reproductionskills. Assessment of the students should be made on the basis of written examinations, project work, assignments, seminars, and group discussions, reports of organizations providing internship / placement facilities to 
students and the work done by students in the legal aid clinic of the law school.

\section{MASTER'S PROGRAMME}

As Masters programme is conceived as a bridge between the Bachelor degree and the Research degree in law, an attempt should be made to provide opportunity for an exhaustive and intensive study of the chosen fields of specialization. In order to avoid unnecessary repetition to courses and enable students to make a comprehensive and critical study of the courses prescribed for the LL.M. examination, LL.M. should not be treated as an enlarged LL.B. but instead should aim to develop the necessary expertise in traditional as well as the emerging branches of law. In view of globalization-induced challenges for legal education LL.M. courses should be reframed to include higher components of public international law, comparative law, conflict of laws, regional law, international trade and finance, and environmental law, internet law, procurement law, transnational justice, international criminal law, and development law. The LL.M. curriculum should also aim at to expose students to global issues like environmental degradation, poverty, the common heritage of mankind, international crime, terrorism, pandemics and the media and transnational dimensions of core subjects such as contracts, criminal law, family law, intellectual property and labour law should form part of the courses designed for the Masters degree. As students holding a masters degree may be better placed to take up transnational legal practice, they should be equipped with the ability to adapt to different cultures and to communicate effectively with lawyers of other jurisdictions and legal traditions.

National law universities, global law schools and premier centres of legal learning may prepare their students for practice in a neighbouring member state of SAARC, ASEAN and Asia-Pacific region. Students may also be encouraged to study a foreign language so that they may develop cross-cultural skills. In brief, the focus of the LL.M. study should be on knowledge, research, and service.

In tune with the aims and objectives of the LL.M. study appropriate modes of instruction and assessment should be evolved. Lecture cum seminar method with a heavy dose of group discussions 
and research and project work may be adopted as padagogic tools while imparting education to LL.M. students.

While BCI recognizes the need to strengthen the current LL.M. degree, it is also exploring the option of a nine to twelve month LL.M. degree programme that can be undertaken immediately. Further, in line with the recommendations of the National Knowledge Commission (20062009) in its Report of March 2009, and the $184^{\text {th }}$ Report of Law Commission of India, the Bar Council of India (2002) has proposed that the requirements of an LL.M. degree to teach law be relaxed in the case of candidates with an LL.B. degree who are 'exceptional and demonstrate ability to teach.' These proposals may help candidates with a foreign LL.M. degree of nine month duration but who are currently ineligible for the post of law teachers in our country, to get appointments in national law universities and law departments of universities, but they would also affect adversely the prestige of an LL.M. degree and the overall standards of legal education in our country. Simply put, these proposals are retrograde ones and therefore should not be pursued further.

\section{DEVELOPING A RESEARCH CULTURE IN LAW SCHOOLS AND UNIVERSITIES}

Lately India has emerged as a global player in international relations and is poised to become an economic as well as strategic power in the days to come provided it becomes the second or third largest trading power at the international level. But India can become a major trading power in the world only when it rapidly transforms itself from being a materialbased economy to a knowledge-based economy. To this end, we need new perspectives, new thinking and new innovations in the field of knowledge-production and transformation of the created knowledge into patents and copyrighted material. In the specific context of legal education, we need to become a leading producer in the world of new legal knowledge and ideas. According to Prime Minister, Dr. Manmohan Singh, India of the $21^{\text {st }}$ Century will be made in universities and other centres of learning and they shall remake India and the world. It therefore becomes imperative for law schools to undertake original and pathbreaking research to create new knowledge and ideas that will help the country to address the age old problems of poverty, unemployment, 
illiteracy and disease and respond to new challenges that India is facing in today's interdependent world.

To develop a serious culture of research in our country the following measures need to be taken without any further delay: making analytical writing skills and research methodology an integral aspect of the LL.B. programmes, rationalizing the teaching load to leave faculty members sufficient time for research, granting sabbatical leave to faculty to undertake research; creating incentives if research results in peer reviewed publications either through additional increments (beyond the UGC scheme) or in any other appropriate manner. Institutionalizing periodic faculty seminars; establishing quality peer reviewed journals; prescribing research output as one of the criteria for promotion; creating a database of citations to identify the most cited and influential writings as well as considering such data for promotional purposes and making a dissertation mandatory in the LL. M. programme will also help to improve the quality of legal research. Some of these measures have already been implemented but the remaining can be implemented when UGC and central and state governments sanction the required faculty positions and grants for the purpose.

To promote cutting-edge research on various aspects of law and also serve as a think-tank for advising the government and international fora, the Knowledge Commission has recommended the establishment of four autonomous well networked Centres for Advanced Legal Studies and Research (CALSAR), one in each region. The CALSARs, according to the National Knowledge Commission, would perform the following functions and objectives; maintaining adequate linkages and institutionalized interaction opportunities with law schools and universities; providing continuing legal education for faculty; publishing a peer reviewed journal of international quality; facilitating multidisciplinary approaches to law; institutionalizing arrangements for scholars in residence; organizing workshops and undertaking in-depth research on new and developing areas. While recognizing the need for setting up institutions like CALSARs in different parts of the country, it is humbly submitted that on being given adequate funds established premier centres of legal learning like Banaras and Delhi Law Schools will be able to perform these functions better with a lower budget. 


\section{MEASURES TO ATTRACT AND RETAIN BETTER FACULTY}

The success of any reform measures, and, at a wider level, the quality of legal education in the country, is dependent upon the quality of teaching faculty at the law schools. Recognizing the role and functions of the faculties in the upgradation of the standards of legal education both the Knowledge Commission and the Bar Council have given due attention to the need to attract and retain better faculty. As one step towards addressing this concern, the Bar Council of India has taken measures to ensure that members of law faculty are paid according to the minimum pay scales prescribed by the UGC Pay Commission. The National Knowledge Commission has gone many steps further, and recommended salary differentials within and betwen universities and law schools. Salary differentials, according to the Knowledge Commission, could be considered as a means to retain quality talent and also a culture of excellence. The Commission has also recommended incentives like increasing existing promotional schemes and avenues to promote faculty members, providing fully paid sabbaticals and adequate House Rent Allowance (HRA); instituting awards to honour reputed teachers and researchers at national and international levels and allowing faculty to take up consultancy assignments and legal practice in courts. With regard to opportunities in legal education that may be provided to law teachers as a means to attract and retain talented faculty, the Knowledge Commission is of the view that these reforms "need to be introduced in a balanced, reasonable and regulated manner to ensure adequate incentivisation for faculty without compromising on the maintenance of consistent academic quality.”

\section{REGULATORY ROLE OF THE BAR COUNCIL OF INDIA}

Legal education in India is regulated by multiple agencies including University Grants Commission and Bar Council of India. Constituted under Section 4 of the Advocate Act, 1961 BCI is an apex body for the entire legal profession in India and regulates legal education by laying down minimum standards of legal education required for students, grants permission for establishment of new law colleges and performs several other functions related to inspection, recognition and accreditation. 
Reservations, however, have been expressed from time to time in respect of the role of BCI vis-à-vis legal education on the ground that being a professional body, the Council does not have both power and expertise to improve the overall quality of legal education.

Today a widely shared view of legal educators is in favour of liberation of such education from the dominant control of the Bar Council. The National Knowledge Commission went further and recommended the setting up of a new regulatory mechanism under the Independent Regulatory Authority for Higher Education (IRAHE), vested with powers to deal with all aspects of legal education and whose decisions are binding on the institutions teaching law and on the Union and State Governments. The Knowledge Commission also recommended the creation of the Standing Committee for Legal Education. The Standing Committee should have a vision both of social and international goals, to deal with all aspects of legal education and to cater to the needs of the present and the future. Even prior to the report of the Knowledge Commission submitted to the Prime Minister of India, Law Commission in its $184^{\text {th }}$ Report, while envisaging BCI as the principal body for regulating standards of legal education, in conjunction with UGC and other technical bodies contemplated 'effective consultation' between BCI and UGC in order to ensure professional regulation of legal education as well as adequate representation of academicians.

Facing the prospects of being divested of its regulatory authority over legal education in the event of the establishment of a Commission on Higher Education and Research, which will replace UGC and other education regulatory authorities, Bar Council of India adopted several legal education reform measures. In the first place, it composed its Legal Education Committee as provided for under Rule 2 (xvi) of the 2008 BCI Rules, which provision contemplated a distinguished Professor of Law as well as the Chairman of UGC to be members of the Legal Education Committee. The Legal Education Committee contemplated the constitution of a body of experts to be associated with the BCI inspection team, the constitution of a Selection Commission for the purposes of identifying and appointing competent faculties of law colleges, as well as the provision of better salaries and facilities to law faculties. The Bar Council of India also approved the report of the three-member committee created by the Supreme Court of India in Bar Council of India v. Bonnie FOI Law College and $\mathrm{Ors}^{16}$ and resolved in favour of

$16 \quad$ Case No. 22337 of 2008, decided April 2, 2010. 
the constitution of a National Legal Knowledge Council comprising legal luminaries and academicians as well as members from various socially relevant fields such as technology, science, media, economics, social sciences etc. It has established the Directorate of Legal Education with the responsibility of continuing legal education, teachers training, advanced specialized professional courses, education programme for Indian students seeking registration after obtaining Law Degree from a foreign university, research on professional legal education and standardization, seminar and workshop, legal research and any other assignment that may be assigned to it by the Legal Education Committee and the Bar Council of India.

Responding to relevant contemporary issues concerning legal education and acting on most of the recommendations made by the Law Commission in its $184^{\text {th }}$ Report, the Recommendations made by the National Knowledge Commission as well as the suggestions and recommendations received from the three-member Committee on Reform of Legal Education, BCI enacted its 2008 rules and took several reform initiatives and declared the time-table for their implementation. These reform proposals relate to increased representation of academia in BCI Legal Education Committee, prior permission for imparting legal education, reformed mode of inspection, approval of institutions and accreditation / rating system for law colleges.

$\mathrm{BCI}$ is also going to implement a system of bench-marking and quality evaluation of law schools. According to a note on Proposed Directions for Reform (BCI) the measures used to evaluate law schools will include the following factors: the preference shown by candidates for admission to a law school in the uniform admission procedure for admission, the success rate of graduates from a law school in the 'All India Bar Examinations,' the quality and extent of infrastructure and resources available at law school; and the number of publications by faculty from law school in peer-reviewed publications. Efforts will also be made to put in place measures against plagiarism. These parameters would not only be used to measure faculty quality and performance but would also be a part of the factors evaluated when accrediting law schools.

Another important reform proposal relates to standardization of the academic calendar. The Bar Council believes that an academic calendar for all law schools will remove existing impediments to the implementation of uniform change measures and also the other difficulties 
that students face on various fronts, such as in participating in an exchange programme between law schools.

In view of the above mentioned measures taken by BCI for improving the quality of legal education the three-member Committee on Reform of Legal Education is of the firm view that BCI's role vis-à-vis regulation of legal education standards in the country cannot be undermined, but, rather should be re-affirmed and preserved. While the final decision in the matter has to be taken by the Central Government, the recently introduced Bar Examination for the purpose of admitting law graduates to the Bar is bound to undercut the legitimacy of the Council's control on legal education. The justification offered for a Bar examination is that it would ensure maintenance of standards in the legal profession as well as standardization and constant innovation in the standards of curriculum, teaching methodology etc. So far law graduates produced by law schools were eligible to be admitted to the Bar without appearing in any Bar examinations subject to the caveat that law schools were recognized by the Bar Council and they awarded a three year / five year professional degree in law as per the syllabi prescribed by the Council. But now when the Council has decided to hold the said examination, there is hardly any incentive for law schools to accept the regulatory powers of the Council in the field of legal education. Considering that more than 75 per cent law graduates do not have slightest inclination to join the bar, there is perhaps a need to rethink on the duration and content of instructions for the LL. B. students. Since the Bar Council merely prescribes syllabi and issues instructions but is not a grants giving body and as such is not in a position to provide any material support that more than 900 law schools across the country may need to improve the quality of legal education, would it not be prudent for the Council to make a retreat from legal education and confine itself to exercise of its powers to conduct the Bar examination and to regulate discipline in the legal profession?

\section{CONCLUSION}

In conclusion, the current debate on legal education reform raises a number of questions on which greater dialogue is needed among the vast number of Indian law teachers. Globalization-induced changes in international relations have altered the nature of legal profession today 
and as legal profession is closely tied up with legal education, time has come for our legal educators and the regulatory authorities concerned to move forward and restructure legal education so that our law graduates can also successfully compete in the emerging global market of transnational legal service. But while transforming legal education to meet the challenges of globalization is undoubtedly one among several considerations requiring improvements in pedagogy and curriculum in legal education the need to promote the rule of law, democracy, constitutionalism, respect for human rights and social justice and to strengthen India as a global power should remain the main drivers of legal reforms education in our country. 